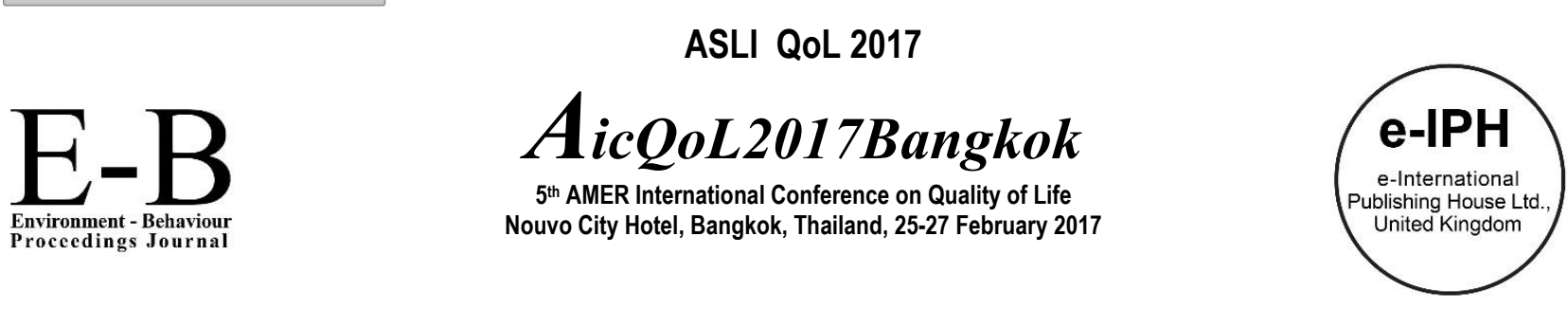

\title{
Spatial Adaptation of Protected Area Buffer Zones in Urban Setting: Impact on human and conservation agenda
}

\author{
Che Bon Ahmad 1*, Jamalunlaili Abdullah ${ }^{1}$, Jasmee Jaafar ${ }^{1}$, Ahamad Nazrin Aris Anuar ${ }^{1}$ \\ ${ }^{1}$ Faculty of Architecture, Planning and Surveying, Universiti Teknologi MARA 40450 Shah Alam, Selangor, Malaysia
}

\begin{abstract}
It is considerably challenging task to have a buffer zone (BZ) around protected areas (PA) in the urban area due to the conflict of interest between conservation and development. There is a need for 'win-win situation'. This research is to identify the impact of a potential buffer zone on human and conservation of natural environment which derived from the stakeholders' understanding. In-depth interviews with stakeholders of the PA and their surroundings were carried out. The findings suggested that a 'dual purpose' BZ - environmental conservation and socio-economic benefits are suitable for the FRIM area.
\end{abstract}

Keywords:; Buffer Zone Concept; Protected Areas; Urban Setting; FRIM, Malaysia

ISSN: 2398-42870 2017. The Authors. Published for AMER ABRA by e-International Pub lishing House, Ltd., UK. This is an open access article under the CC BYNCND license (http://creativecommons.org/licenses/by-nc-nd/4.0/). Peer-review under responsibility of AMER (Association of Malaysian Environment-Behaviour Researchers), ABRA (Association of Behavioural Researchers on Asians) and cE-Bs (Centre for Environment-Behaviour Studies), Faculty of Architecture, Planning \& Surveying, Universiti Teknologi MARA, Malaysia.

\subsection{Introduction}

The basis of having a BZ is to create some sort of "shock absorber" around the PAs. These would also act as transition zones from areas of high-intensity protection to areas of lesser protective requirements. To have a BZ around PA is a considerably difficult work in areas whereby the physical boundaries or limits of the conservation area end abruptly at the edges of human settlements or high density of land use development. Even PAs are also fragmented and occupied by human habitations. Thus, maintenance of ecological balance and conservation of biodiversity should be done in a holistic manner by encompassing all related aspects of ecology, economy, and society. Identification of appropriate BZs around PAs is of vital significance in this regard. This is to make sure the viable of the PAs from the continuous harm caused by human development. BZs may serve as a 'dual-function' - conservation of the natural resources or biodiversity and livelihood of the local people. It is important to identify the BZ-stakeholders relationship, how these may be improved through the mutual understanding and consensus translated into the criteria for BZ. Its detail out the stakeholder experiences with decision-making process (perception about involvement and influence); stakeholder relationship (potential cooperation and conflicts) and existing relationship (cooperation and conflict).

\subsection{Literature Review}

One of the main reasons for the low management effectiveness is that the location of the PA in an urban area has led to an increase in the number of threats to it and has strongly influenced the biogeographic characteristics. The urbanization in and around the area has resulted in the PA being isolated, with no connection to other ecosystems through ecological corridors. Both direct measures and strategic planning are required to facilitate continuous improvement of the management of PAs (de Almeida, Olímpio, Pantalena, de Almeida, \& de Oliveira Soares, 2016) and it includes the management of adjacent land, BZs (Deb, Ahmed, \& Datta, 2014).

Du, Penabaz-Wiley, Njeru, \& Kinoshita (2015) reveals the absolute necessity of combining two approaches in integrating PAs and their surroundings for future conservation and sustainable development are site specific-approach. Its deals on accurate scientific and

\footnotetext{
${ }^{*}$ Corresponding author. Tel.: 0619-669-5857

E-mail address: chebon848@salam.uitm.edu.my
}

ISSN: 2398-4287@ 2017. The Authors. Published for AMER ABRA by e-International Publishing House, Ltd., UK. This is an open access article under the CC BYNC-ND license (http://creativecommons.org/licenses/by-nc-nd/4.0/). Peer-review under responsibility of AMER (Association of Malaysian Environment-Behaviour Researchers), ABRA (Association of Behavioural Researchers on Asians) and CE-Bs (Centre for Environment-Behaviour Studies), Faculty of Architecture, Planning \& Surveying, Universiti Teknologi MARA, Malaysia.

DOI: http://dx.doi.org/10.21834/e-bpj.v2i5.683 
rationale way to integrate PAs and their surrounding and process-oriented approach which concern with reducing conflicts among stakeholders of PAs and their surroundings. It is suggested that environmental system of the PAs and their surroundings; economic activities superseded conservation activities (unsuccessful conserving its resources because it allows urban areas and production activities which could be detrimental to the site as various human activities are incomparable with conservational goals (de Almeida et al., 2016).

BZs may provide solutions; act as a 'shock absorber' between conservation and development area. Although the requirement of BZ for PA is stated in many national and international guidelines, policy and regulations, their approach and criteria are not explicitly mentioned (Town and Country Planning, Malaysia, 2011). There is a need for suitable criteria for BZ. The underlying solution may conjoin between environmental conservation, economic development and community involvement (Fauzi \& Misni, 2016).

\subsection{Stakeholders role}

Stakeholders are important because local knowledge, in particular, should be considered a valuable source and although it is always a challenge in finding a balance between local and more general priorities, the outcome of any conciliation is more likely to have positive results if the approaches adapt to the local context (Sheil, Nasi, \& Johnson, 2004). Stakeholders' agreement is required to determine the necessary decision (e.g., managers, adjacent communities, legal enforcement agencies). In general, broad participation becomes a norm in good practice. Nonetheless, it is effective only if they involve in the planning process and the outcome of the process favor all parties (Suškevičs, Tillemann, \& Külvik, 2013). A reasonable initial point is to simply improve the integration of local stakeholders and their needs into the planning process of determining the criteria. These decisions may be due to economic considerations of the existing and future changes of the land uses. As decisions are made, stakeholders should be aware of the potential changes in desired buffer functions that occur and the potential compromise of long-term values. In most cases, a buffer width can be determined which meet landowner needs while also providing an adequate function of BZs (Liu et al., 2010). In actuality, many BZs constitute a geographical expansion of the state authority beyond the boundaries of the PAs and into the communities and economic entities (man's land) in which the establishment of it resulted in 'new forms of state intervention and restrictions on land use activities'(Stræde \& Treue, 2006). Sadly to say, this approach might be unwise without integrating the impact of human to BZ and vice versa.

\subsection{Study area}

The study area is Forest Research Institute of Malaysia (FRIM), which was declared as a National Heritage site in 2012 and now gearing towards UNESCO Heritage Site. Being one of the largest man-made forests in the world, it can serve as a model for reforestation, forest management and forest protection for the world. FRIM is located in Kepong, Kuala Lumpur and is surrounded by the Bukit Lagong Forest Reserve on one side and new developments, mainly residential and commercial areas, on the other. It stakeholders consists of Land Office, Forestry Department, Environmental Department, District Office, local community and etc.

As a national heritage site, FRIM enjoys secure protection in law. However, while the area is relatively large in local terms, it is relatively narrow in width and thus is vulnerable to disturbance and nonconforming physical development in the peripheries. The need for the study arose out of increasing pressure for various forms of development in these peripheries, which had the potential to negatively affect the integrity of the PA and the unique resources of the area, especially their biodiversity, water production, and scenic values. Landscape transformation by a number of land uses such as agriculture, commercial afforestation, and the new settlement was found to be a significant threat to the natural beauty of much of the area.

\subsection{Methodology}

The study uses a qualitative approach with in-depth interviews with the stakeholders. Regardless of their level of interest and influences, identifying the stakeholders were based on their expertise, knowledge, experience and position in the organization The representatives of an organization are likely to be the director or the person in-charged that is reliable to be interviewed. Six (6) key important stakeholders were identified - FRIM, Selayang Municipal Council, Forestry Department of Peninsular Malaysia, representative of residences (Taman Ehsan and Taman Bidara) and WWF Malaysia. Although there were more stakeholders of FRIM, six are selected as this study is meant for a pilot stage in order to clarify the thoughts and opinions of the stakeholders regarding the concept and criteria of $\mathrm{BZ}$, and become a basis for further detail study which will be carried out later.

An interview with a set of pre-judgmental variables was used in the semi- structured interviews. The data were transcribed from the voice recorder using Microsoft software and further analyzed for content analysis using ATLAS.ti 7. Data has been analyzed and condensed and coded into suitable information revealed by the respondents. The unit of analysis was based on the organization and the expert's from the management level that were selected.

\subsection{Findings}

Table 1 below shows the stakeholders understanding of current concept and propose 'dual-purpose' concept for buffer zone in urban area while Table 2 shows the impacts of potential BZ on human and conservation agenda. 
Table 1. Understanding of buffer zones' current concept and future concept

\begin{tabular}{|c|c|c|c|c|}
\hline Respondent & $\begin{array}{l}\text { Understanding of buffer zone } \\
\text { concept (existing) }\end{array}$ & $\begin{array}{l}\text { Factors determining the } \\
\text { criteria of buffer zone }\end{array}$ & $\begin{array}{l}\text { Understanding of proposed } \\
\text { buffer zone 'dual-purpose' } \\
\text { concept }\end{array}$ & $\begin{array}{l}\text { Parties to be involved in } \\
\text { buffer zone development }\end{array}$ \\
\hline $\begin{array}{l}\text { Forestry } \\
\text { Department of } \\
\text { Peninsular } \\
\text { Malaysia (FDPM) }\end{array}$ & $\begin{array}{l}\text { An area allocated around the forest } \\
\text { meant for protection purposes. It } \\
\text { determines by specific functions and } \\
\text { benefits of the forest reserve } \\
\text { according to } 11 \text { forest classes } \\
\text { assign by the dept. } \\
\text { *virgin jungle forest (VGR), } \\
\text { permanent forest estate (PFE) and } \\
\text { water catchment area do not require } \\
\text { BZ }\end{array}$ & $\begin{array}{l}\text { Size of logging } \\
\text { Width of river stream } \\
\text { Size of research plot } \\
\text { Size of sample plot } \\
\text { Size of salt lake area } \\
\text { Wildlife coverage (small } \\
\text { mammal, elephant and tiger) }\end{array}$ & $\begin{array}{l}\text { Benefit to both parties. } \\
\text { Contribute to } \\
\text { preservation and } \\
\text { improvement of the } \\
\text { natural habitat and } \\
\text { enhancement of the } \\
\text { environmental services } \\
\text { provided by the forest } \\
\text { reserve (i.e. watershed } \\
\text { protection). } \\
\text { Must abide to law and } \\
\text { regulations set for it. }\end{array}$ & $\begin{array}{l}\text { FRIM } \\
\text { Selayang District Office } \\
\text { Local community } \\
\text { State Land Dept } \\
\text { National Heritage Dept }\end{array}$ \\
\hline $\begin{array}{l}\text { Selayang } \\
\text { Municipal Council } \\
\text { (SMC) }\end{array}$ & $\begin{array}{l}\text { An area acts as a border to 'rest } \\
\text { down' two different land use } \\
\text { activities. It may be in the form of } \\
\text { open spaces, railways, highways, } \\
\text { power lines and rivers. } \\
\text { "BZ is government land unless } \\
\text { mutual agreement is made between } \\
\text { two landowners }\end{array}$ & $\begin{array}{l}\text { Existing land use } \\
\text { Future land use } \\
\text { Constraints } \\
\text { Potentials }\end{array}$ & $\begin{array}{l}\text { Benefit to conservation } \\
\text { purposes and community. }\end{array}$ & $\begin{array}{l}\text { FRIM } \\
\text { Heritage Dept } \\
\text { Forestry Dept } \\
\text { Planning Dept } \\
\text { Local community } \\
\text { Local authority } \\
\text { State Land Dept } \\
\text { Water and Irrigation Dept }\end{array}$ \\
\hline $\begin{array}{l}\text { Forest Research } \\
\text { Institute of } \\
\text { Malaysia (FRIM) }\end{array}$ & $\begin{array}{l}\text { An area around, inside or outside } \\
\text { the protected area allocated for } \\
\text { protection of protected area and } \\
\text { cater for specific functions. }\end{array}$ & $\begin{array}{l}\text { Involve living and non-living } \\
\text { thing, people live inside } \\
\text { protected areas. } \\
\text { Threat and awareness of } \\
\text { community on the } \\
\text { conservation of protected } \\
\text { area. } \\
\text { To address human-wildlife } \\
\text { conflicts. }\end{array}$ & Win-win situation. & $\begin{array}{l}\text { FRIM } \\
\text { Heritage Department } \\
\text { State Forestry } \\
\text { Department } \\
\text { Town and Country } \\
\text { Planning Dept } \\
\text { Local community } \\
\text { Local Authority } \\
\text { State Land Dept } \\
\text { Water and Irrigation Dept }\end{array}$ \\
\hline $\begin{array}{l}\text { Taman Ehsan } \\
\text { community }\end{array}$ & $\begin{array}{l}\text { Open space between two areas, } \\
\text { i.e., residential and conservation } \\
\text { reserve }\end{array}$ & $\begin{array}{l}\text { Type of activity } \\
\text { Type of basic amenities }\end{array}$ & $\begin{array}{l}\text { Good concept - 'two in } \\
\text { one' concept } \\
\text { (Activities in buffer zones } \\
\text { could benefit } \\
\text { communities and, buffer } \\
\text { zones as shield to } \\
\text { protected areas). } \\
\text { Issues with areas with no } \\
\text { space between protected } \\
\text { areas and residential } \\
\text { areas. }\end{array}$ & $\begin{array}{l}\text { FRIM } \\
\text { Local authority }\end{array}$ \\
\hline $\begin{array}{l}\text { Taman Bidara } \\
\text { community }\end{array}$ & $\begin{array}{l}\text { Buffer zone is to protect the forest } \\
\text { area. }\end{array}$ & Benefit to community. & $\begin{array}{l}\text { Benefit to FRIM and } \\
\text { residence. } \\
\text { In the form of open } \\
\text { space, landscape area } \\
\text { and basic facilities. }\end{array}$ & $\begin{array}{l}\text { FRIM } \\
\text { Government agencies }\end{array}$ \\
\hline $\begin{array}{l}\text { World Wildlife } \\
\text { Fund, Malaysia } \\
\text { (WWFM) }\end{array}$ & $\begin{array}{l}\text { Transition land which } \\
\text { complementing both parties' } \\
\text { benefits. } \\
\text { "existing or introduced forest }\end{array}$ & $\begin{array}{l}\text { Topography } \\
\text { Biodiversity coverage } \\
\text { Ecosystem coverage } \\
\text { Adjacent land use activities }\end{array}$ & $\begin{array}{l}\text { Provide benefit to both } \\
\text { parties -lt involve } \\
\text { ecosystem of } \\
\text { conservation area and } \\
\text { people live inside and at } \\
\text { the surroundings. } \\
\text { Community involvement } \\
\text { is of high priority. } \\
\text { Buffer zones protect the } \\
\text { integrity and authenticity } \\
\text { of the protected areas. It } \\
\text { sizes should be } \\
\text { appropriate for in-situ and } \\
\text { ex-situ activities. }\end{array}$ & $\begin{array}{l}\text { FRIM } \\
\text { National Heritage } \\
\text { Department } \\
\text { State Forestry } \\
\text { Department } \\
\text { State and Federal } \\
\text { Town and Country } \\
\text { Planning Department } \\
\text { Local community } \\
\text { Other NGOs }\end{array}$ \\
\hline
\end{tabular}

Table 2. Impact of potential BZ on human activities and conservation agenda

\begin{tabular}{llll}
\hline Theme & Factors & $\begin{array}{l}\text { Impact of potential BZ on human } \\
\text { activities }\end{array}$ & $\begin{array}{l}\text { Impact of potential BZ conservation agenda } \\
\text { Legal }\end{array}$ \\
$\begin{array}{llll}\text { Law } \\
\text { Land tenure } \\
\text { Legal use }\end{array}$ & $\begin{array}{l}\text { Abide to new regulation - changes of } \\
\text { governances }\end{array}$ & $\begin{array}{l}\text { Contributes to the protection and conservation } \\
\text { of heritage site, natural ecosystem and its } \\
\text { biodiversity that benefits the nation and }\end{array}$ \\
\hline
\end{tabular}




\begin{tabular}{|c|c|c|c|}
\hline & Illegal use & & worldwide \\
\hline Planning & $\begin{array}{l}\text { Management plan (sustainability } \\
\text { concept) } \\
\text { Zoning } \\
\text { Planning standard and guidelines } \\
\text { Ex-situ and in-situ factors } \\
\text { Land use } \\
\text { Existing land use } \\
\text { Future land use } \\
\text { Constraints } \\
\text { Potentials }\end{array}$ & $\begin{array}{l}\text { Abide to new regulation, guidelines } \\
\text { and enforcements, future land uses } \\
\text { such as low density development } \\
\text { BZ as open space provide recreations } \\
\text { BZ as a railway, highway, power line, } \\
\text { rivers } \\
\text { Existing and introduced forest provide } \\
\text { areas for communities and amenities, } \\
\text { infrastructure } \\
\text { Limit and constraints on land uses } \\
\text { Abide to regulations and } \\
\text { enforcements }\end{array}$ & $\begin{array}{l}\text { Abide to new regulation and guidelines, future } \\
\text { land uses - opted for eco-tourism instead of } \\
\text { high impact of tourism. } \\
\text { Additional area for conservation purposes. }\end{array}$ \\
\hline Biogeo-graphic & $\begin{array}{l}\text { Size } \\
\text { Vulnerability } \\
\text { Shape } \\
\text { Connectivity }\end{array}$ & $\begin{array}{l}\text { Physical barriers at no land area } \\
\text { (fences, ditches, canals) } \\
\text { Determine by the human constrains }\end{array}$ & $\begin{array}{l}\text { Act as edge effect control - gap or shield } \\
\text { between protected area and development area }\end{array}$ \\
\hline Environment & $\begin{array}{l}\text { Landform (topography) } \\
\text { Edaphic (mineral and soil) } \\
\text { Natural vegetation } \\
\text { climate } \\
\text { Biophysical factors }\end{array}$ & Provide activities in the area & $\begin{array}{l}\text { Restrict activities } \\
\text { BZ as function of the forest (forest for } \\
\text { production and conservation) limits the } \\
\text { permitted activities } \\
\text { Supporting zoning system (water catchment } \\
\text { areas) } \\
\text { BZ on private land restrict land use activities } \\
\text { Improvement of natural habitat } \\
\text { Environmental services - water shed } \\
\text { protection } \\
\text { Wildlife coverage }\end{array}$ \\
\hline $\begin{array}{l}\text { Socio-economic } \\
\text { (social process } \\
\text { shaped economic } \\
\text { activity) }\end{array}$ & $\begin{array}{l}\text { Income generation from } \\
\text { conservation activities, population }\end{array}$ & $\begin{array}{l}\text { Provide economic activities (eco- } \\
\text { tourism) } \\
\text { Income generation } \\
\text { Community benefit } \\
\text { Support conservation activities }\end{array}$ & $\begin{array}{l}\text { Limitation of economic activities } \\
\text { Income generation } \\
\text { Community benefit } \\
\text { Support livelihood of people }\end{array}$ \\
\hline
\end{tabular}

\subsection{Discussion and Analysis}

Figure 1 above shows interesting findings on the current understanding of the concept of BZ. FDPM for example, they define BZ specifically based on their forest management classes assigned by the department. Some of the classes do not require BZ for example area bordering the study area (FRIM) is virgin jungle forest reserved for water catchment area Thus, it is proposed that the entire catchment area can become a buffer zone for FRIM. On the other hand, SMC in their land use development requirements define BZ as 'rest down' area between two types of land uses. For example, power line and open space can become a BZ. This led to questionable issues whether or not poses negative impact to PA. FRIM, according to their management plan define BZs as an area inside or outside the PA allocated for protection of PA and cater for specific functions. It involves living and non-living thing and also human-wildlife conflicts. The surrounding communities understand BZ as an open space to protect the protected areas whilst WWF Malaysia define BZs as a transition land which complementing both parties' benefits.

Based on Table 1 above too, the study further found that the factors contributing to the criteria derived from the interviews were extensive. Some are overlaps and the other are differ and it may be influenced by the current practice of the related management requirements of the area which are mainly based on the objectives and purposes of the management plan or guidelines. For example, FDPM allocates certain size of BZ based on the size of logging are, size of forest sample plot and size of salt lake area. Whilst, SMC determine the BZs based on the existing and future land uses of the area, FRIM determine the criteria for their BZ is based on conservation-human conflicts and human-wildlife conflicts.

Remarkably, all stakeholders agreed on the proposed BZ concept which collectively agreed on the concept - dual purpose (balancing the conservation agenda and human livelihood). They understand the concept which provide benefit for community and at the same time conserve the environment. The stakeholders further suggested the parties that should take part in the BZ development and most of them are national entities.

Table 2 above shows the findings on the impact of $B Z$ on human activities and conservation agenda are quite comprehensive. To ease the readings, the findings have been divided into 5 themes and several factors for each theme, derived from qualitative analysis using ATLAS. ti software. There are legal, planning, bio-geographic, environment and socio-economic. The findings in general shows the positive impact as well as negative impacts especially under the 'planning' theme where the land use at potential BZ area has to abide to certain regulations such as only low density development are permitted. On the positive side of impacts, the delineated BZ may become the area for recreation for the surrounding communities. 


\subsection{Conclusion and Recommendations}

The findings reveal the absolute necessity of combining the 'dual purpose' for future conservation and sustainable development of buffer zone for protected areas. Although there are negative impacts of BZ towards conservation agenda and human activities, the finding shows that the positive impacts may look more significant. The environmental conservation, economic development and human activities must be in interchangeably among each other in order to have a 'win-win' delineation of buffer zone.

\section{Acknowledgements}

The author gratefully acknowledges all participated agencies, especially Dewan Bandaraya Kuala Lumpur, all public participated groups, Universiti Teknologi MARA, Shah Alam and Kementerian Pendidikan Malaysia for their help and financial supports. The authors also acknowledge the constructive comments for reviewing the manuscript.

\section{References}

De Almeida, L. T., Olímpio, J. L. S., Pantalena, A. F., de Almeida, B. S., \& de Oliveira Soares, M. (2016). Evaluating ten years of management effectiveness in a mangrove protected area. Ocean \& Coastal Management, 125, 29-37. doi:10.1016/j.ocecoaman.2016.03.008

Deb, S., Ahmed, A., \& Datta, D. (2014). An alternative approach for delineating eco-sensitive zones around a wildlife sanctuary applying geospatial techniques. Environmental Monitoring and Assessment, 186(4), 2641-51. doi:10.1007/s10661-013-3567-7

Du, W., Penabaz-Wiley, M. S., Njeru, M. A., \& Kinoshita, I. (2015). Models and Approaches for Integrating Protected Areas with Their Surroundings: A Review of the Literature. Sustainability . doi:10.3390/su7078151

Fauzi, N. S. M., \& Misni, A. (2016). Geoheritage Conservation: Indicators Affecting the Condition and Sustainability of Geopark - A Conceptual Review. Procedia Social and Behavioral Sciences, 222, 676-684. doi:10.1016/j.sbspro.2016.05.224

Sheil, D., Nasi, R., \& Johnson, B. (2004). Ecological Criteria and Indicators for Tropical Forest Landscape: Challenges in the Search for Progress. Ecology and Society, 9(1):7. Retrieved from http://www.ecologyandsociety.org/vol9/iss1/art7

Suškevičs, M., Tillemann, K., \& Külvik, M. (2013). Assessing the relevance of stakeholder analysis for national ecological network governance: The case of the Green Network in Estonia. Journal for Nature Conservation, (0). doi:http://dx.doi.org/10.1016/j.jnc.2012.12.007

Sheil, D., Nasi, R., \& Johnson, B. (2004). Ecological Criteria and Indicators for Tropical Forest Landscape: Challenges in the Search for Progress. Ecology and Society, 9(1):7. Retrieved from http://www.ecologyandsociety.org/vol9/iss1/art7

Strohbach, M. W., Arnold, E., \& Haase, D. (2012). The carbon footprint of urban green space-A life cycle approach. Landscape and Urban Planning, 104(2), 220-229. doi:10.1016/j.landurbplan.2011.10.013

Suškevičs, M., Tillemann, K., \& Külvik, M. (2013). Assessing the relevance of stakeholder analysis for national ecological network governance: The case of the Green Network in Estonia. Journal for Nature Conservation, (0). doi:http://dx.doi.org/10.1016/j.jnc.2012.12.0oi.org/10.1016/j.jnc.2012.12. 